\title{
Prevalence of Glucose-6-Phosphate Dehydrogenase (G6PD) Deficiency in India: A Systematic Review
}

\author{
I. I. Shah'1, J. Jarullah², B. Jarullah ${ }^{*}$ \\ ${ }^{1}$ Department of Biotechnology, Kadi Sarva Vishwavidyalaya, Gandhinagar, India \\ ${ }^{2}$ King Fahd Medical Research Center, King Abdulaziz University, Jeddah, Saudi Arabia \\ Email: iishah1806@yahoo.com, jumanaj@gmail.com, *bjarullah@yahoo.com
}

How to cite this paper: Shah, I.I., Jarullah, J. and Jarullah, B. (2018) Prevalence of Glucose-6-Phosphate Dehydrogenase (G6PD) Deficiency in India: A Systematic Review. Advances in Bioscience and Biotechnology, 9, 481-496.

https://doi.org/10.4236/abb.2018.99033

Received: August 16, 2018

Accepted: September 18, 2018

Published: September 21, 2018

Copyright (c) 2018 by authors and Scientific Research Publishing Inc. This work is licensed under the Creative Commons Attribution International License (CC BY 4.0).

http://creativecommons.org/licenses/by/4.0/

\begin{abstract}
Glucose-6-Phosphate Dehydrogenase (G6PD) deficiency is the most common enzyme deficiency of human erythrocyte affecting more than 400 million people worldwide. In India, G6PD deficiency was first reported in 1963 and since then various investigations have been conducted across country. The objective of this work was to study the prevalence of G6PD deficiency in different ethnic, caste and linguistic groups of Indian population. A systematic search of published literature was undertaken and the wide variability of G6PD deficiency has been observed ranging from $0 \%-30.7 \%$ among the different caste, ethnic, and linguistic groups of India. It was observed that the incidence of G6PD deficiency was found to be considerably higher among the tribes $(9.86 \%)$ as compared to other ethnic groups (7.34\%) and significantly higher in males as compared to females.
\end{abstract}

\section{Keywords}

Glucose-6-Phosphate Dehydrogenase, G6PD, Deficiency, India, Prevalence

\section{Introduction}

G6PD deficiency is the X-chromosome linked erythrocyte enzyme deficiency. G6PD deficiency causes a hematologic disorder, namely haemolytic anaemia, and it was as a result of investigation of haemolytic anaemia that brought this common enzymatic deficiency to light. In 1973, it was estimated that about 300 million people worldwide were G6PD deficient, but now these numbers have been increased [1]. G6PD deficiency being an X-linked condition, males may be either G6PD normal or G6PD deficient hemizygotes, whereas females can be 
normal homozygotes or deficient homozygotes or heterozygotes.

\subsection{Detection of G6PD deficiency}

Glucose-6-phosphate dehydrogenase(G6PD; EC 1.1.1.49) enzyme plays a vital role in the generation of NADPH and ribose-5-phosphate in the pentose phosphate pathway [1]. NADPH functions as an electron donor and provides the reducing energy required for regeneration of reduced Glutathione which ultimately protects the cells against oxidative damage. Though G6PD deficiency affects every cell in the body, its primary effects are hematological because in the erythrocyte this pathway is the only source of NADPH [2]. There are various methods available for detection of G6PD deficiency, but quantitative measurement of G6PD enzyme by measuring the reduction of NADP to NADPH using ultraviolet spectrophotometer is the basic diagnostic approach used commonly for detection of G6PD deficiency. Other than that, in a dye reduction test, the reduction of NADPH was linked to the reduction of the visible dye brilliant cresyl blue [1]. Various other tests such as methylene blue, MTT tetra sodium, dichloro-indophenol or methemoglobin were also developed [3] [4]. In recent times, fluorescent spot test is more popular for rapid testing of deficiency in which reduction of NADPH is observed directly by virtue of its fluorescence, instead of linking the reduced pyridine nucleotide to a dye [5]. These screening procedures are quite robust in the detection of the fully developed defect in males, but they fall short in the determination of female heterozygotes and in patients with relatively mild forms of G6PD deficiency.

\subsection{Occurrence of G6PD Deficiency}

G6PD deficiency affects around 10\% of the total population of world. The highest prevalence of G6PD deficiency mainly regards in tropical Africa, the Middle East, tropical and subtropical Asia, Papua New Guinea and various Mediterranean regions [1] [6] [7].

India, a south Asian country having second largest population in the world, varying in various castes, ethnic and linguistic groups. Also geographically and environmentally India has a great variation, which is also responsible for difference among population. In India investigations on G6PD deficiency have been started after it was firstly reported by Baxi et al. in 1961 [8]. Since then, various studies regarding prevalence of G6PD deficiency among various population groups have been conducted across India. India being a malarial endemic country, the treatment course requires primaquine drugs which is generally conducted without routine G6PD screening. This makes patients vulnerable to prescription of potentially haemolytic drugs, especially putting G6PD deficient individuals at risk of serious complications. Therefore, in current report existing literature regarding occurrence of G6PD deficiency have been reviewed to estimate the prevalence of G6PD deficiency across India and highlighting the areas where more research is needed. 


\section{Methods}

A systematic literature search from 1961 to 2016, through PubMed/MEDLINE, Google scholar, Wiley online library databases was performed in as follows. Relevant publications were identified through free text search using keywords such as Glucose-6-Phosphate Dehydrogenase (G6PD) deficiency, India, Prevalence without any restriction on the year and language of publication. Various combinations of these keywords such as "G6PD in India", "Prevalence of G6PD in India", "Glucose-6-Phosphate Dehydrogenase (G6PD) deficiency", "Prevalence of Glucose-6-Phosphate Dehydrogenase (G6PD) deficiency", "Prevalence of Glucose-6-Phosphate Dehydrogenase (G6PD) deficiency in Indian population", "G6PD deficiency incidence and India", "Incidence of G6PD deficiency in India", "Incidence of Glucose-6-Phosphate Dehydrogenase deficiency in India", "Incidence of G6PD deficiency in Indian population", "Distribution of G6PD deficiency in India" etc. were used. Although there was no bar on language, English was more preferred. Additionally articles were also obtained through citation tracking of reviews, articles and original papers along with direct receipt of full text articles from some authors or co-authors. The duplicated articles were eliminated from the above mentioned search. Titles and abstracts of each identified article was then checked for eligibility based on the following criteria:

Inclusion criteria:

-Primary data, population based epidemiological study

-Hospital based study

Exclusion criteria:

-Age group of subjects: less than 15 years

-Studies related to only clinical manifestation of G6PD deficiency

The epidemiological studies of G6PD deficiency in Indian population were included for this systematic review. Hospital based prevalence studies were also selected. Although, studies carried out amongst neonates, children and young adults (less than 15 years of age) were excluded. Studies based on clinical manifestations of G6PD deficiency were also excluded as they mainly focused on clinical aspects and hardly provided information regarding the incidence of G6PD deficiency. Review articles regarding prevalence or clinical manifestations of G6PD deficiency were also excluded.

Finally, the full text of eligible articles and reports were evaluated to obtain detailed information regarding the prevalence of G6PD deficiency in various ethnically and regionally diverse population of India. The data was evaluated and the systematic review was conducted according to PRISMA guidelines.

\section{Results}

\subsection{Selection Procedure}

Figure 1 shows the PRISMA flow diagram of systematic search. Among the 360 records identified and retrieved from databases and other sources, 134 articles were found to be associated with G6PD deficiency in India after initial screening 


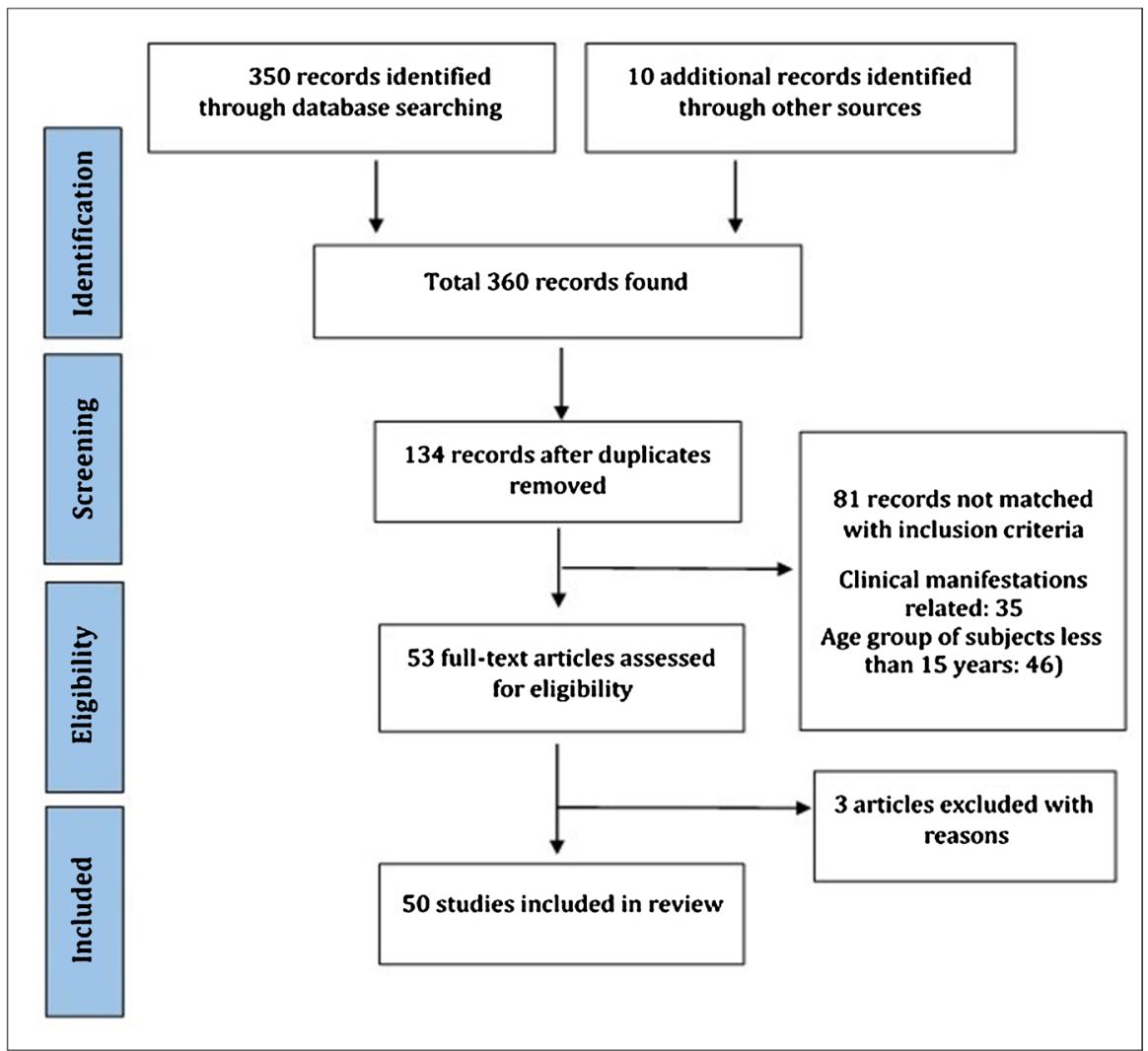

Figure 1. PRISMA Flow diagram of systematic review search.

and removal of duplicates. These articles were manually checked by titles and abstracts and 81 articles were found to be irrelevant to the inclusion criteria. Of remaining 53 articles, 3 articles were excluded-1 for incomplete information, 1 for lack of publishing in peer reviewed journal, 1 for duplication of data. Finally 50 original articles were included for this systematic review.

\subsection{Prevalence of G6PD Deficiency in India}

In the current review, the distribution of G6PD deficiency in the various population groups from total 20 states and 3 union territories of India have been summarized below which have been categorized into Northern India, Southern India, Western India, Eastern India, Central India, North-eastern India and Island regions. These studies have been carried out in total 49,929 subjects among which 22,431 subjects belong from urban population and 27,498 from tribal population. From compilation of these studies, it has been observed that the prevalence of G6PD deficiency highly varies from 0 to $30.7 \%$ among the different caste, ethnic, and linguistic groups of India (Table 1) [8]-[59].

\subsection{Northern India}

Northern India consists of states of Jammu \& Kashmir, Punjab, Haryana, Uttaranchal, Uttar Pradesh and union territories of Delhi and Chandigarh. According to census 2011 the tribes are not found in regions of Punjab, Haryana, 
Table 1. Distribution of G6PD deficiency in the different population groups in India.

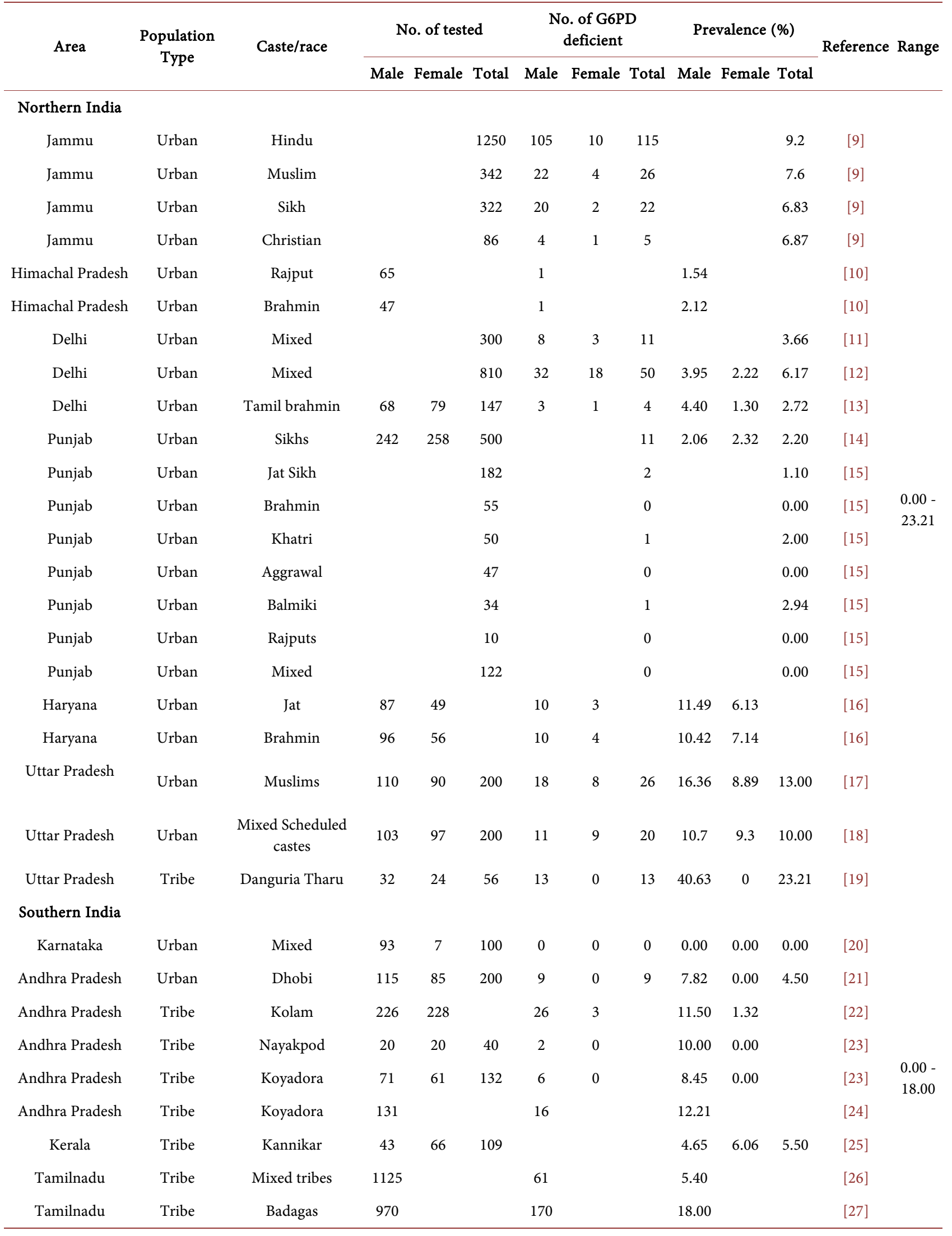




\section{Continued}

\begin{tabular}{|c|c|c|c|c|c|c|c|c|c|c|c|c|c|}
\hline Western India & & & & & & & & & & & & & \\
\hline Maharashtra & Urban & Bhanushali (cutchee) & 139 & 90 & & 17 & 3 & & 12.2 & 3.33 & & {$[28]$} & \\
\hline Maharashtra & Urban & Mixed & 81 & 29 & 110 & 6 & 9 & 15 & 7.41 & 31.03 & 13.64 & {$[8]$} & \\
\hline Maharashtra & Urban & Visa oswal jain & & & 107 & & & 3 & & & 2.80 & [29] & \\
\hline Maharashtra & Urban & Audich brahmin & & & 141 & & & 5 & & & 3.50 & [29] & \\
\hline Maharashtra & Urban & Lad vania & & & 128 & & & 1 & & & 0.78 & [29] & \\
\hline Maharashtra & Urban & Bohra & 67 & & & & & & & & 0.00 & {$[30]$} & \\
\hline Maharashtra & Urban & Khoja & 108 & & & & & & & & 2.00 & {$[30]$} & \\
\hline Maharashtra & Urban & Moplah & 94 & & & & & & & & 0.00 & {$[30]$} & \\
\hline Maharashtra & Urban & Misgar & 75 & & & & & & & & 0.50 & {$[30]$} & \\
\hline Maharashtra & Urban & Mixed muslim & 120 & & & & & & & & 2.00 & {$[30]$} & \\
\hline Maharashtra & Urban & Baniya & 51 & 82 & & 0 & 0 & & 0.00 & 0.00 & & {$[31]$} & \\
\hline Maharashtra & Urban & Bhandari & 50 & 95 & & 0 & 0 & & 0.00 & 0.00 & & {$[31]$} & \\
\hline Maharashtra & Urban & Bhaiya & 41 & 25 & & 1 & 0 & & 2.43 & 0.00 & & {$[31]$} & \\
\hline Maharashtra & Urban & Muslim & 318 & 220 & & 3 & 0 & & 0.94 & 0.00 & & {$[31]$} & \\
\hline Maharashtra & Urban & Brahmin & 361 & 403 & & 5 & 0 & & 1.38 & 0.00 & & {$[31]$} & \\
\hline Maharashtra & Urban & Jain & 207 & 281 & & 3 & 0 & & 1.45 & 0.00 & & {$[31]$} & \\
\hline Maharashtra & Urban & Sikh & 91 & 110 & & 1 & 0 & & 1.10 & 0.00 & & {$[31]$} & \\
\hline Maharashtra & Urban & Kayastha & 36 & 52 & & 1 & 0 & & 2.77 & 0.00 & & {$[31]$} & $0.00-$ \\
\hline Maharashtra & Urban & Lohana & 117 & 45 & & 9 & 1 & & 7.69 & 0.22 & & [31] & 27.94 \\
\hline Maharashtra & Urban & Maratha & 593 & 515 & & 1 & 0 & & 0.17 & 0.00 & & {$[31]$} & \\
\hline Maharashtra & Urban & Christian & 45 & 161 & & 2 & 0 & & 4.44 & 0.00 & & {$[31]$} & \\
\hline Maharashtra & Urban & Parsi & 19 & 26 & & 2 & 1 & & 10.53 & 3.85 & & {$[31]$} & \\
\hline Maharashtra & Urban & Artisan & 259 & 247 & & 2 & 1 & & 0.77 & 0.40 & & {$[31]$} & \\
\hline Maharashtra & Urban & Schedule caste & 294 & 233 & & 2 & 0 & & 0.68 & 0.00 & & {$[31]$} & \\
\hline Maharashtra & Urban & Dhangar & 1385 & & & 3 & & & 0.22 & & & {$[32]$} & \\
\hline Maharashtra & Urban & Nava-budha & & & 51 & & & 0 & & & 0.00 & {$[33]$} & \\
\hline Maharashtra & Urban & Parsis & & & 133 & & & 23 & & & 17.30 & {$[33]$} & \\
\hline Maharashtra & Urban & Chitpavan Brahmin & & & 81 & & & 1 & & & 1.23 & [33] & \\
\hline Maharashtra & Urban & $\begin{array}{l}\text { Deshastha regvedi } \\
\text { brahmin }\end{array}$ & & & 76 & & & 1 & & & 1.31 & {$[33]$} & \\
\hline Maharashtra & Urban & $\begin{array}{l}\text { Chandra seniya } \\
\text { kayastha prabhu }\end{array}$ & & & 96 & & & 2 & & & 2.08 & {$[33]$} & \\
\hline Maharashtra & Urban & Maratha & & & 13 & & & 0 & & & 0.00 & {$[33]$} & \\
\hline Rajasthan & Urban & Mixed & & & 1798 & & & 126 & & & 7.00 & {$[34]$} & \\
\hline Rajasthan & Urban & Mixed & & & 3810 & & & 216 & & & 5.67 & {$[35]$} & \\
\hline Gujarat & Urban & Vataliya prajapati & 272 & 113 & 385 & 76 & 11 & 87 & 27.94 & 9.73 & 22.60 & [36] & \\
\hline Gujarat & Urban & Brahmin & & & 4 & & & 0 & & & 0.00 & {$[37]$} & \\
\hline
\end{tabular}


Continued

\begin{tabular}{|c|c|c|c|c|c|c|c|c|c|c|c|c|c|}
\hline Gujarat & Urban & Darbar & & & 14 & & & 0 & & & 0.00 & {$[37]$} & \\
\hline Gujarat & Urban & Jain & & & 4 & & & 0 & & & 0.00 & {$[37]$} & \\
\hline Gujarat & Urban & Lohana & & & 10 & & & 1 & & & 10.00 & {$[37]$} & \\
\hline Gujarat & Urban & Muslim & & & 14 & & & 0 & & & 0.00 & {$[37]$} & \\
\hline Gujarat & Urban & Patel & & & 8 & & & 0 & & & 0.00 & {$[37]$} & \\
\hline Gujarat & Urban & Sindhi & & & 2 & & & 0 & & & 0.00 & {$[37]$} & \\
\hline Gujarat & Urban & Harijan & & & 26 & & & 7 & & & 26.92 & {$[37]$} & \\
\hline Gujarat & Urban & Luhar & & & 3 & & & 0 & & & 0.00 & {$[37]$} & \\
\hline Gujarat & Urban & Khatri & & & 2 & & & 0 & & & 0.00 & {$[37]$} & \\
\hline Gujarat & Urban & Satwara & & & 5 & & & 0 & & & 0.00 & {$[37]$} & \\
\hline Gujarat & Urban & Suthar & & & 4 & & & 0 & & & 0.00 & [37] & \\
\hline Gujarat & Urban & Vataliya prajapati & 985 & 659 & 1644 & 275 & 84 & 359 & 27.90 & 12.20 & 22.00 & {$[38]$} & \\
\hline $\begin{array}{c}\text { Dadra \& nagar } \\
\text { haveli }\end{array}$ & Urban & Rajput & 47 & & & 1 & & & 2.13 & & & {$[39]$} & \\
\hline $\begin{array}{c}\text { Dadra \& nagar } \\
\text { haveli }\end{array}$ & Tribe & Warli tribe & 79 & & & 8 & & & 10.10 & & & {$[40]$} & \\
\hline $\begin{array}{c}\text { Dadra \& nagar } \\
\text { haveli }\end{array}$ & Tribe & Dodhia & 74 & & & 10 & & & 13.50 & & & {$[41]$} & \\
\hline Rajasthan & Tribe & Kumhar & 101 & 56 & & 5 & 1 & & 4.95 & 1.79 & & {$[42]$} & \\
\hline Rajasthan & Tribe & Garasiya & & & 368 & & & 56 & & & 15.21 & {$[43]$} & \\
\hline Rajasthan & Tribe & Mixed & & & 4007 & & & 509 & & & 12.70 & {$[35]$} & \\
\hline Rajasthan & Tribe & Mixed & & & 1124 & & & 203 & & & 18.06 & {$[34]$} & \\
\hline Gujarat & Tribe & Bharwad & & & 16 & & & 0 & & & 0.00 & [37] & \\
\hline Gujarat & Tribe & Koli & & & 22 & & & 0 & & & 0.00 & [37] & \\
\hline Gujarat & Tribe & Rabari & & & 16 & & & 2 & & & 12.50 & {$[37]$} & \\
\hline Maharshtra & Tribe & Bhils & & & 215 & & & 16 & & & 7.44 & [33] & \\
\hline Maharshtra & Tribe & Pawras & & & 87 & & & 3 & & & 3.45 & [33] & \\
\hline Maharshtra & Tribe & Katkaris & & & 77 & & & 6 & & & 7.80 & {$[33]$} & \\
\hline \multicolumn{14}{|l|}{ Eastern India } \\
\hline West bengal & Urban & Mixed & & & 583 & 6 & 2 & 8 & 1.23 & 2.06 & 1.37 & {$[44]$} & \\
\hline West bengal & Urban & Bengali & & & 103 & & & 4 & & & 3.88 & {$[45]$} & \\
\hline West bengal & Urban & Nepali & & & 25 & & & 2 & & & 8.00 & {$[45]$} & \\
\hline West bengal & Urban & $\begin{array}{l}\text { Uttarpradeshi and } \\
\text { bihari }\end{array}$ & & & 18 & & & 2 & & & 11.11 & {$[45]$} & $0.00-$ \\
\hline West bengal & Urban & Muslim & & & 17 & & & 1 & & & 5.88 & {$[45]$} & 30.70 \\
\hline West bengal & Urban & Christian & & & 5 & & & 0 & & & 0.00 & {$[45]$} & \\
\hline West bengal & Urban & Punjabi & & & 3 & & & 0 & & & 0.00 & {$[45]$} & \\
\hline West bengal & Urban & Marathi & & & 1 & & & 0 & & & 0.00 & {$[45]$} & \\
\hline West bengal & Urban & South Indian & & & 1 & & & 0 & & & 0.00 & {$[45]$} & \\
\hline
\end{tabular}




\section{Continued}

\begin{tabular}{|c|c|c|c|c|c|c|c|c|c|c|c|c|c|}
\hline Orissa & Tribe & Kolha & 209 & & & 34 & & & 15.30 & & & {$[46]$} & \\
\hline Orissa & Tribe & Santal & 106 & & & 13 & & & 12.30 & & & {$[46]$} & \\
\hline Orissa & Tribe & Bathudi & 212 & & & 24 & & & 11.30 & & & {$[46]$} & \\
\hline Orissa & Tribe & Munda & 131 & & & 16 & & & 12.20 & & & {$[46]$} & \\
\hline Orissa & Tribe & Jaunga & 380 & & & 52 & & & 13.70 & & & {$[46]$} & \\
\hline Orissa & Tribe & Gonda & 98 & & & 7 & & & 7.10 & & & {$[46]$} & \\
\hline Orissa & Tribe & Bhuyan & 176 & & & 25 & & & 14.20 & & & {$[46]$} & \\
\hline Orissa & Tribe & Didayi & 478 & & & 8 & & & 1.70 & & & {$[46]$} & \\
\hline Orissa & Tribe & Kandha & 625 & & & 20 & & & 3.20 & & & {$[46]$} & \\
\hline Orissa & Tribe & Bondo & 449 & & & 2 & & & 0.40 & & & {$[46]$} & \\
\hline Orissa & Tribe & Paroja & 204 & & & 11 & & & 5.40 & & & {$[46]$} & \\
\hline Orissa & Tr0ibe & Koya & 101 & & & 0 & & & 0.00 & & & {$[46]$} & \\
\hline Orissa & Tribe & Oroan & 121 & & & 11 & & & 9.10 & & & {$[46]$} & \\
\hline Orissa & Tribe & Holva & 190 & & & 0 & & & 0.00 & & & {$[46]$} & \\
\hline Orissa & Tribe & Kissan & 71 & 20 & 92 & & & & 9.78 & 4.30 & 14.13 & {$[25]$} & \\
\hline Orissa & Tribe & Dudh kharia & & & 422 & 41 & 45 & 86 & 9.70 & 10.70 & 20.40 & {$[47]$} & \\
\hline Orissa & Tribe & Dhelki kharia & & & 345 & 54 & 51 & 105 & 15.60 & 14.80 & 30.40 & {$[47]$} & \\
\hline Orissa & Tribe & Paraja Bhuyan & & & 213 & 32 & 16 & 48 & 15.00 & 7.50 & 22.50 & {$[47]$} & \\
\hline Orissa & Tribe & Paik Bhuyan & & & 244 & 26 & 15 & 41 & 10.60 & 6.10 & 16.80 & {$[47]$} & \\
\hline Orissa & Tribe & Paudi Bhuyan & & & 379 & 30 & 22 & 52 & 7.90 & 5.80 & 13.70 & {$[47]$} & \\
\hline Orissa & Tribe & Dudh kharia & & & 422 & 36 & 45 & 89 & 8.50 & 10.70 & 19.20 & {$[48]$} & \\
\hline Orissa & Tribe & Dhelki kharia & & & 345 & 55 & 51 & 106 & 15.90 & 14.80 & 30.70 & {$[48]$} & \\
\hline West bengal & Tribe & Rajbangshi & & & 100 & & & 12 & & & 12.00 & [49] & \\
\hline West bengal & Tribe & Santhal & & & 164 & & & 23 & & & 14.03 & [33] & \\
\hline \multicolumn{14}{|l|}{ Central India } \\
\hline Madhya Pradesh & Urban & Sindhi & & & 508 & & & 4 & & & 0.80 & {$[50]$} & \multirow{6}{*}{$\begin{array}{l}0.8- \\
19.23\end{array}$} \\
\hline Madhya Pradesh & Tribe & Bhil & 120 & & & 8 & & & 6.70 & & & {$[51]$} & \\
\hline Chhattisgarh & Tribe & Muria & & & 300 & 24 & 6 & 30 & 8.00 & 2.00 & 10.00 & {$[52]$} & \\
\hline Chhattisgarh & Tribe & Maria & & & 182 & 24 & 3 & 27 & 13.18 & 1.65 & 14.83 & {$[52]$} & \\
\hline Chhattisgarh & Tribe & Halba & & & 372 & 38 & 7 & 45 & 10.21 & 1.83 & 12.04 & {$[52]$} & \\
\hline Chhattisgarh & Tribe & Bhatra & & & 104 & 16 & 4 & 20 & 15.23 & 3.85 & 19.23 & {$[52]$} & \\
\hline \multicolumn{14}{|l|}{$\begin{array}{l}\text { North-eastern } \\
\text { India }\end{array}$} \\
\hline Manipur & Urban & Muslim & & & 136 & & & 29 & & & 21.32 & {$[53]$} & \multirow{5}{*}{$\begin{array}{l}1.86- \\
15.79\end{array}$} \\
\hline Manipur & Urban & Brahmin & & & 115 & & & 12 & & & 9.44 & [53] & \\
\hline Manipur & Tribe & Kabui & & & 51 & & & 4 & & & 7.84 & [53] & \\
\hline Nagaland & Tribe & Ao Naga & 394 & 314 & 708 & & & & 9.21 & 1.86 & & {$[54]$} & \\
\hline Nagaland & Tribe & Angami Naga & 85 & 65 & 150 & 23 & 10 & 33 & 27.06 & 15.39 & 22.00 & {$[55]$} & \\
\hline
\end{tabular}




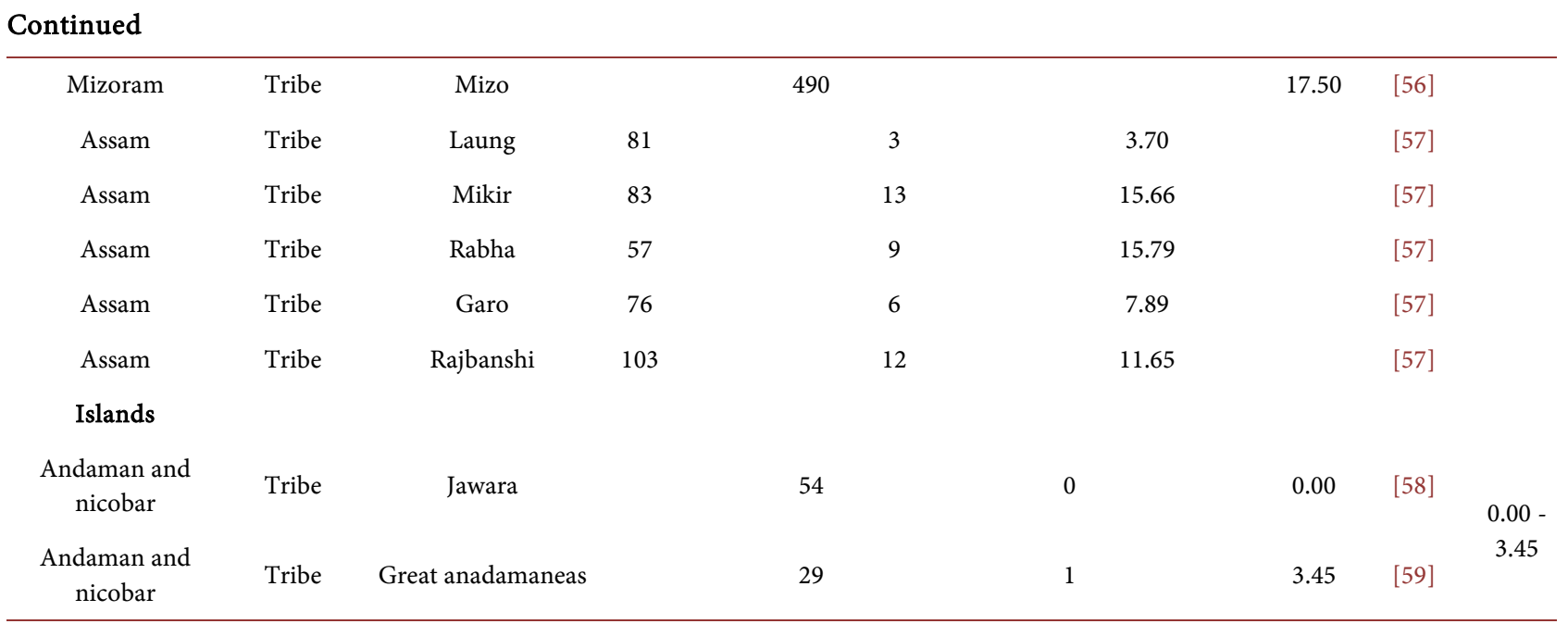

Chandigarh and Delhi. Hence, the prevalence of G6PD deficiency in these regions have been reported only from urban population which ranges between 0 to 13\% [9]-[18]. However prevalence of G6PD deficiency in Danguria Tharu tribe from Uttar Pradesh have been reported up to $23.21 \%$. The same study reported $40.63 \%$ prevalence in males but further investigation is required due to small population size [19]. Remarkably a study, conducted in south Indian Brahmins settled in Delhi revealed similarity of frequency of G6PD deficiency among other south Indian caste groups, and also with the migrated population [13].

\subsection{Southern India}

Southern India consists of states of Andhra Pradesh, Karnataka, Kerala and Tamilnadu. In Southern India, investigations regarding G6PD deficiency have been carried out more in tribal population than the urban populations. In urban population, while a study from Karnataka reported absence of G6PD deficiency in mixed population, the frequency of G6PD deficiency have been reported upto 7\% among Dhobis of Andhra Pradesh [20] [21]. Investigations in various tribes have reported frequency of G6PD deficiency ranging from $0 \%$ to $12 \%$ in Andhra Pradesh, upto $6 \%$ in Kerala and about 5\% to $18 \%$ in Tamilnadu [22]-[27].

\subsection{Western India}

It is notable that the investigations regarding occurrence of G6PD deficiency have been reported extensively from the Western India comprising of states of Gujarat, Rajasthan, Maharashtra and union territory of Dadra \& Nagar Haveli. The occurrence of G6PD deficiency was firstly reported by Baxi et al. in 1961 in Bombay suggesting its wide distribution in the country [8]. As it was the very first investigation of G6PD deficiency in Maharashtra let alone in India, it played a key role in starting the investigation on G6PD deficiency in India. In western India, the investigations of this deficiency have been conducted amongst several tribal as well urban populations comprising of Parsees, Cutchee Bhanushalis, Marathas, Dhangars, Bhils, Pawars, Muslims, Hindus, Jains, Christians, Brah- 
mins, Katkaris, Sikhs, Kayasthas, Bhandaris, Baniyas, Garasiyas, Kumhars, Damors, Minas, Patidars, Rajputs, Bhois, Panchals, Patels, Lohanas, Bohras, Sompuras, Darbars, Harijans, Luhars, Warlis, Dodhias, and many more [8] [28]-[43]. Although various investigations have reported occurrence of G6PD deficiency frequenting from $0 \%$ to $18 \%$ in general, frequency of G6PD deficiency have been reported up to $27.9 \%$ in Vataliya Prajapati community from Gujarat which is the second highest in country [36]. Also in another study conducted on mixed population, the prevalence of G6PD deficiency was found as high as $26.92 \%$ among Harijan population from Gujarat, but further study is required due to less stratified sampling [37]. Even though some reports show high prevalence of G6PD deficiency in certain communities, it is notable that the prevalence of G6PD deficiency in overall population of Gujarat are low with the drastic variation in the prevalence amongst the tribal and urban population.

\subsection{Eastern India}

Eastern India consists of states of Bihar, Jharkhand, Orissa and West Bengal. Most of the investigations regarding G6PD deficiency have been done mainly in regions of Orissa and West Bengal. Relatively high prevalence of G6PD deficiency have been reported in Eastern India that ranges between 0 to 30.7\% [25] [33] [44]-[49]. Investigation on frequency of G6PD deficiency among urban population have been reported only from West Bengal ranging from $0 \%$ to $11 \%$ [45]. Whereas in the same region it was found upto $12 \%$ and $14 \%$ in Rajbangshi and Santhal tribes respectively [33] [49]. Prevalence of G6PD deficiency has been reported upto $30.7 \%$ in Dhelki Kharia tribe of Orissa which is the highest found prevalence till date in India [48]. Other than that, investigations have been carried out in various other tribes such as Dudh Kharias, Bhuyans, Marathis, Kissans, Kolhas, Kondhs, Gonds, Bhumiz and several more from Orissa [25] [46] [47] [48].

\subsection{Central India}

Central India Comprises of Madhya Pradesh and Chhatisgarh states. Frequency of G6PD deficiency have been reported $0.8 \%$ among Sindhi community and 6.7\% among Bhil tribe from Madhya Pradesh [50] [51]. The frequency of G6PD deficiency ranges from $6 \%$ to $19 \%$ in various tribes of Chhattisgarh [52].

\subsection{North-Eastern India}

The North-Eastern region of India consists of the contiguous states of Arunachal Pradesh, Assam, Meghalaya, Manipur, Mizoram, Nagaland and Tripura, which are predominantly inhabited by tribes. Frequency of G6PD deficiency in these area ranges between $0 \%$ to $27.6 \%$ among various tribes such as Nagas, Mikirs, Rabhas, Garo, Rangbanshi etc. [53] [54] [55] [56] [57].

\subsection{Islands of India}

Reports regarding G6PD deficiency from Andaman and Nicobar islands are 
scarce. A study revealed complete absence of G6PD deficiency in Jawara tribe [58], while in another study frequency of G6PD deficiency was reported $3.4 \%$ in Great Andamanese tribes but further study is needed due to small sample size [59].

\section{Discussion}

Globally more than 400 million people are suspected to be G6PD deficient. The overall G6PD allele frequency is believed to be around $8 \%$ and the high population density makes Asia the center of weight of G6PD deficiency-burdened populations [6] [60]. High frequency of G6PD deficiency is mainly found in malaria endemic regions. India being the second highest populated country with great ethnic, geographical and racial diversity is also one of the most malaria affected country worldwide and thus assumed to have high frequency of G6PD deficiency.

The data reported here have been collected from various surveys conducted by different researchers and considerable differences were seen in the methods adopted for field surveys, the mode of collection of blood samples and especially methods for screening of G6PD deficiency. Although, various methods such as quantitative spectrophotometric assays, methemoglobin reduction test, $\mathrm{BCB}$ test, MTT linked test, fluorescent spot test etc. are available for detection of G6PD deficiency, detection of heterozygous population is still problematic. Therefore, the work towards developing new methods for enzyme detection-especially in heterozygous females is essential.

In this comprehensive study, the wide variability of G6PD deficiency has been observed ranging from $0 \%-30.7 \%$ among the different caste, ethnic, and linguistic groups of India. The area wise distribution revealed frequency of G6PD deficiency ranging between $0 \%-30.70 \%$ in Eastern India to $0 \%-27.9 \%$ in Western India. The prevalence of G6PD deficiency was found ranging from $0 \%$ $23.21 \%$ in Northern India to $0 \%-18 \%$ in Southern India. Whereas it was found ranging between $1.86 \%-15.71 \%$ in North-eastern India and $0 \%-19.23 \%$ in Central India, the range in the island regions of India is reported to be even lower.

It also revealed in this review, that the incidence of deficiency was found to be considerably higher among the tribes $(9.86 \%)$ as compared to other ethnic groups (7.34\%) and significantly higher in males as compared to females. The investigations regarding distribution of G6PD deficiency have been reported extensively from the western parts of India, whereas reports from North-eastern and Islands regions of India are scarce. In Southern India, most of the studies have been carried out among tribal populations, while in Northern India mostly among the urban populations. Although this review is a comprehensive amalgam of data from all over India, wherein studies have been carried out in several regions including Maharashtra, Gujarat, Rajasthan, West Bengal, Orissa, Madhya Pradesh, Tamilnadu, Kerala, Delhi, Haryana, Punjab, Jammu, Uttar Pradesh, 
Assam, Nagaland. However, many areas of India are still left unexplored. Moreover, the review includes data from 1969 to 2016 with several reports targeting few ethnic groups. Such discrimination in the sampling might lead to chances of errors in the analyzed disposition to G6PD amongst the population. It is therefore emphasized that further evaluation of the clinical and prognostic aspects of G6PD deficiency among Indian population needs to be explored.

\section{Funding}

This research received no specific grant from any funding agency in the public, commercial, or not-for-profit sectors.

\section{Conflicts of Interest}

The authors declare that there is no conflict of interest.

\section{References}

[1] Beutler, E. (1994) G6PD Deficiency. Blood, 84, 3613-3636.

[2] Kirkman, H.N., Gaetani, G.D., Clemons, E.H. and Mareni, C. (1975) Red Cell NADP + and NADPH in Glucose-6-Phosphate Dehydrogenase Deficiency. Journal of Clinical Investigation, 55, 875-878. https://doi.org/10.1172/JCI107998

[3] Betke, K., Beutler, E., Brewer, G.J., et al. (1967) Standardization of Procedures for the Study of Glucose-6-Phosphate Dehydrogenase. WHO Technical Report Series, $366,1-56$.

[4] Gall, J.C., Brewer, G.J. and Dern, R.J. (1965) Studies of Glucose-6-Phosphate Dehydrogenase Activity of Individual Erythrocytes: The Methemoglobin-Elution Test for Identication of Females Heterozygous for G6PD Deficiency. The American Journal of Human Genetics, 17, 359-368.

[5] Fairbanks, V.F. (1962) A Simple Method for Detection of Erythrocyte Glucose-6-Phosphate Dehydrogenase Deficiency(G-6-PD Spot Tets). Blood, 20, 591-601.

[6] Howes, R.E., Piel, F.B., Patil, A.P., et al. (2012) G6PD Deficiency Prevalence and Estimates of Affected Populations in Malaria Endemic Countries: A Geostatistical Model-Based Map. PLOS Medicine, 9, e1001339. https://doi.org/10.1371/journal.pmed.1001339

[7] Howes, R.E., Battle, K.E., Satyagraha, A.W., Baird, J.K. and Hay, S.I. (2013) G6PD Deficiency: Global Distribution, Genetic Variants and Primaquine Therapy. Advances in Parasitology, 81, 133-201. https://doi.org/10.1016/B978-0-12-407826-0.00004-7

[8] Baxi, A.J., Balakrishnan, V. and Sanghvi, L.D. (1961) Deficiency of Glucose-6-Phospahte Dehydrogenase-Observations on a Sample from Bombay. Cur rent Science, 1, 16-17.

[9] Verma, V., Saini, R.K., Arya, R.K. and Kaul, B. (1986) Incidence og G6PD Deficiency in the Various Ethnic Groups of Jammu Region (Jammu and Kashmir State). Current Science, 55, 1075-1076.

[10] Kabita, S., Khurana, P., Saraswathy, K.N. and Sachdeva, M.P. (2011) Glucose-6Phosphate Dehydrogenase Deficiency among the Rajputs and Brahmins of Solan District, Himachal Pradesh. Anthropologist, 13, 39-41. https://doi.org/10.1080/09720073.2011.11891175 
[11] Khodke, K., Marwah, S., Buxi, G., Yadav, R.B. and Chaturvedi, N.K. (2001) Incidence of G6PD Deficiency in OPD Cases in a Hospital. Journal, Indian Academy of Clinical Medicine, 2, 349-350.

[12] Sharma, M., Dass, J., Dhingra, B. and Saxena, R. (2011) G6PD Deficiency in Females Screened at Tertiary Care Hospital. Indian Journal of Pathology and Microbiology, 54, 850-851.

[13] Saraswathy, K.N. and Aggarwal, S. (2005) Study of Glucose-6-Phosphate Dehydrogenase Deficiency and Sickle Cell Anemia among the Tamil Brahmins of Delhi. Anthropologist, 7, 69-70. https://doi.org/10.1080/09720073.2005.11890886

[14] Bhalla, N., Chander, J. and Singh, H. (1979) Erythrocytic G6PD Deficiency in Punjabi Sikhs. Acta Haematologica, 62, 54-55. https://doi.org/10.1159/000207537

[15] Sidhu, P.K., Kaur, K., Kumar, I. and Lata, S. (2001) Glucose-6-Phosphate Dehydrogenase Deficiency in Blood Donors: Screening by Micromethaemoglobin Reduction Test. Indian Journal of Pathology and Microbiology, 44, 23-25.

[16] Santhi, A. and Sachdeva, M.P. (2004) Glucose-6-Phosphate Dehydrogenase Deficiency among the Jats and Brahmins of Sampla (Haryana). Anthropologist, 6, 291-292. https://doi.org/10.1080/09720073.2004.11890871

[17] Rai, V. and Kumar, P. (2014) Glucose 6-Phosphate Dehydrogenase Deficiency in Muslim Community Settled in Jaunpur District. Indian Journal of Human Genetics, 20, 96-97. https://doi.org/10.4103/0971-6866.132770

[18] Rai, V. and Kumar, P. (2012) Epidemiological Study of Glucose-6-Phosphate Dehydrogenase Deficiency in Scheduled Caste Population of India. Journal of Anthropology, 2012, Article ID: 984180. https://doi.org/10.1155/2012/984180

[19] Sharma, T.P. and Rajkumari, R. (2010) Glucose-6-Phosphate Dehydrogenase Deficiency in Danguria Tharu Settled in Baharaich District of Uttar Pradesh. Anthropologist, 12, 59-61. https://doi.org/10.1080/09720073.2010.11891132

[20] Krishnamurthy, T., Niveditha, S.R. and Rao, S.S. (2014) Screening for G6PD Deficiency in Blood Donors. International Journal of Biological and Medical Research, 5, 4355-4358.

[21] Ramesh, M., Balakrishna, A. and Veerraju, P. (1993) Sickle Cell Haemoglobin and Glucose-6-Phosphate Dehydrogenase Deficiency among Dhobis of Visakhapatnam, Andhra Pradesh, India. Anthropologischer Anzeiger, 51, 173-177.

[22] Saraswathy, K.N., Elizabeth, A.M., Sachdeva, M.P., Rao, T.S. and Kalla, A.K. (2001) Glucose-6-Phosphate Dehydrogenase among the Kolams of Adilabad, Andhra Pradesh. Anthropologist, 3, 51-55. https://doi.org/10.1080/09720073.2001.11890686

[23] Saraswathy, K.N. and Sachdeva, M.P. (2008) G6PD Deficiency, Sickle Cell Trait, Haptoglobin and Transferrin Polymorphisms among Koyadoras and Nayakpods of Andhra Pradesh. Anthropologist, 10, 163-165. https://doi.org/10.1080/09720073.2008.11891043

[24] Khan, M.P. (1964) Glucose-6-Phosphate Dehydrogenase Deficiency in an Indian Rural Area. Journal of Genetics, 59, 14-18. https://doi.org/10.1007/BF02984132

[25] Devi, S.T., Saran, S.K. and Nair, G. (1993) Study of Glucose-6-Phosphate Dehydrogenase (G6PD) in the Kissan Tribals of Orissa and the Kannikar Tribals of Kerala, India. Anthropologischer Anzeiger, 51, 179-181.

[26] Chalvam, R., Kedar, P.S., Colah, R.B., Ghosh, K. and Mukherjee, M.B. (2008) A Novel R198H Mutation in the Glucose-6-Phosphate Dehydrogenase Gene in the Tribal Groups of the Nilgiris in Southern India. Journal of Human Genetics, 53, 181-184. https://doi.org/10.1007/s10038-007-0225-3 
[27] Sivaraj, B., Radha, R., Vidya, C. and Sanil, R. (2015) Prevalence of Glucose 6 Phosphate Dehydrogenase (G6PD) Deficiency among the Badagas of the Nilgiris. Asian Journal of Biochemical and Pharmaceutical Research, 5, 295-299.

[28] Mehta, B.C., Baxi, A.J., Bhatia, H.M., et al. (1971) Glucose-6-Phosphate Dehrdrogenase Defeciency in the Bhanushai Community-A Survey. Indian Journal of Medical Sciences, 25, 229-230.

[29] Baxi, A.J., Parikh, N.P. and Jhala, H.I. (1969) Incidence of Glucose-6-Phosphate Dehydrogenase Deficiency in Three Gujarati Populations. Humangenetik, 8, 62-63.

[30] Hakim, S.M.A. and Baxi, A.J. (1972) Glucose-6-Phosphate Dehydrogenase Deficiency and Colour-Vision Studies in Indian Muslims. Humangenetik, 15, 90-92.

[31] Mudera, V.C., Mukherjee, M., Dolas, M.P. and Colah, R.B. (1991) Glucose 6 Phosphate Dehydrogenase Deficiency-A Large Survey of Fourteen Different Caste Groups from Bombay. Indian Anthropology, 21, 37-42.

[32] Undevia, J.V., Malhotra, K.C. and Dahodwala, F.A. (1985) G6PD and Hemoglobin Variants among Twelve Endogamous Dhangar Castes of Maharashtra, India. Anthropologischer Anzeiger, 43, 209-215.

[33] Kate, S.L., Mukherjee, B.N., Malhotra, K.C., Phadke, M.A., Mutalik, G.S. and Sainani, G.S. (1978) Red Cell Glucose-6-Phosphate Dehydrogenase Deficiency and Haemoglobin Variants among Ten Endogamous Groups of Maharashtra and West Bengal. Human Genetics, 44, 339-343. https://doi.org/10.1007/BF00394299

[34] Choubisa, S.L. (1991) Abnormal Hemoglobins. Thalassaemia and G6PD Enzyme Deficiency in Rajasthan-Western India. Haematologia (Budap), 24, 153-165.

[35] Choubisa, S.L., Choubisa, D.K. and Choubisa, L. (2003) Focus on Red Cell Genetic Defects and Malaria. Journal of Parasitic Diseases, 27, 99-103.

[36] Joshi, S.R., Patel, R.Z., Patel, H.R., Sukumar, S. and Colah, R.B. (2001) High Prevalence of G6PD Deficiency in Vataliya Prajapati in Western India. Haematologia (Budap), 31, 57-60. https://doi.org/10.1163/15685590151092715

[37] Pathak, R., Chhaiya, S. and Mehta, D. (2013) Prevalence of G6PD Deficiency versus Oxidizing Drugs: A Survey in the Tertiary Care Hospital. International Journal of Basic \& Clinical Pharmacology, 2, 170-176. https://doi.org/10.5455/2319-2003.ijbcp20130310

[38] Gupte, S.C., Patel, P.U. and Ranat, J.M. (2005) G6PD Deficiency in Vataliya Prajapati Community Settled in Surat. Indian Journal of Medical Sciences, 59, 51-56. https://doi.org/10.4103/0019-5359.13903

[39] Devi, N.A. and Sachdeva, M.P. (2009) Sickle Cell Haemoglobin and Glucose-6-Phosphate Dehydrogenase Deficiency among the Rajputs of Dadra and Nagar Haveli. Anthropologist, 11, 45-47. https://doi.org/10.1080/09720073.2009.11891078

[40] Samtani, R., Mondal, P.R. and Saraswathy, K.N. (2008) Glucose-6-Phosphate Dehydrogenase Deficiency and Sickle Cell Hemoglobin among the Warli Tribe of Dadra and Nagar Haveli. Anthropologist, 10, 301-303. https://doi.org/10.1080/09720073.2008.11891066

[41] Asghar, M. and Sachdeva, M.P. (2009) Glucose-6-Phosphate Dehydrogenase Deficiency and Sickle Cell Hemoglobin among the Dhodias of Dadra Nagar Haveli. Anthropologist, 11, 61-62. https://doi.org/10.1080/09720073.2009.11891083

[42] Malik, A. and Sachdeva, M.P. (2000) Glucose-6-Phosphate-Dehydrogenase Deficiency Amonh the Kumhars of District Churu, Rajasthan. Anthropologist, 2, 203-204. https://doi.org/10.1080/09720073.2000.11890659 
[43] Choubisa, S.L. (2009) Sickle Cell Haemoglobin, Thalassaemia and G-6-PD Enzyme Deficiency Genes in Garasiya Tribe Inhabited Malaria Endemic Areas of Sirohi District, Rajasthan (India). The Journal of Communicable Diseases, 41, 13-18.

[44] Chatterjee, M., Ganguly, S., Saha, P., Bera, D.K., Basu, N. and Maji, A.K. (2016) Prevalence of G6PD Deficiency among the Malaria Patients in Urban Kolkata, India-A Clinic Based Study. International Journal of Current Microbiology and Applied Sciences, 5, 738-744. https://doi.org/10.20546/ijcmas.2016.503.086

[45] Chatterjea, J.B. (1966) Haemoglobinopathies, Glucose-6-Phosphate Dehydrogenase Deficiency and Allied Problems in the Indian Subcontinent. Bulletin of the World Health Organization, 35, 837-856.

[46] Nishank, S.S., Chhotray, G.P., Kar, S.K. and Ranjit, M.R. (2008) Molecular Variants of G6PD Deficiency among Certain Tribal Communities of Orissa, India. Annals of Human Biology, 35, 355-361. https://doi.org/10.1080/03014460801961289

[47] Balgir, R.S. (2007) Genetic Burden of Red Cell Enzyme Glucose-6-Phosphate Dehrdrogenase Deficiency in Two Major Schedulrd Tribes of Sundargarh District, Northwestern Orissa, India. Current Science, 92, 768-774.

[48] Balgir, R.S. (2010) Genetic Diversity of Hemoglobinopathies, G6PD Deficiency, and $\mathrm{ABO}$ and Rhesus Blood Groups in Two Isolates of a Primitive Kharia Tribe in Sundargarh District of Northwestern Orissa, India. Journal of Community Genetics, 1, 117-123. https://doi.org/10.1007/s12687-010-0016-y

[49] Dasgupta, A., Mondal, T. and Datta, A.K. (2013) Estimation of G6pd Status in the Rajbangshi Population of Sushrutanagar. IOSR Journal of Pharmacy and Biological Sciences, 6, 51-55.

[50] Balgir, R.S. (2009) Inherited Hemolytic Disorders with High Occurrence of $\beta$-Thalassemia in Sindhi Community of Jabalpur Town in Madhya Pradesh, India RS. The Online Journal of Health and Allied Sciences, 8, 5.

[51] Papiha, S.S., Roberts, D.F., Mukerjee, D.P., Singh, S.D. and Malhotra, M. (1978) A Genetic Survey in the Bhil Tribe of Madhya Pradesh, Central India. American Journal of Physical Anthropology, 49, 179-186. https://doi.org/10.1002/ajpa.1330490205

[52] Basu, S. and Jindal, A. (1995) Red Cell Enzyme Deficiencies in the Tribal Population Groups of the Bastar District, Madhya Pradesh, India. Anthropologischer Anzeiger, 4, 331-335.

[53] Achoubi, N., Asghar, M., Meitei, Y., Sachdeva, M.P., Saraswathy, K.N. and Murry, B. (2010) Haemoglobinopathies and Glucose-6-Phosphate Dehydrogenase Deficiency in a Malaria Endemic Region of Manipur, Northeast India. Anthropological Science, 118, 201-204. https://doi.org/10.1537/ase.090408

[54] Kar, S., Seth, S. and Seth, P. (1992) Prevalence of Malaria in Ao Nagas and Its Association with G6PD and HbE. Human Biology, 64, 187-197.

[55] Seth, P. and Seth, S. (1971) Biogenetical Studies of Nagas: Glucose-6-Phosphate Dehydrogenase Deficienc in Angami Nagas. Human Biology, 43, 557-561.

[56] Dash, S., Chhanhimi, L., Chhakchhuak, L. and Zomawaia, E. (2005) Screening for Haemoglobinopathies and G6PD Deficiency among the Mizos of Mizoram: A Preliminary Study. Indian Journal of Pathology and Microbiology, 48, 17-18.

[57] Das, B.M., Deka, R. and Das, R. (1982) Glucose-6-Phosphate Dehydrogenase Deficiency in Five Populations of Assam, India. Indian Anthropology, 12, 73-75.

[58] Murhekar, K.M. and Murhekar, M.V. (2004) Absence of Hemoglobinopathies and G6PD Deficiency among the Jarawas, a Primitive Negretoid Tribes of Andaman and 
Nicobar Islands. Indian Journal of Human Genetics, 10, 29-30.

[59] Murhekar, K.M., Murhekar, M.V., Murhekar, M.B., et al. (2001) Red Cell Genetic Abnormalities, Beta Globin Gene Haplotypes and APOB Polymorphism in the Great Andamanese a Primitive Negrito Tribe of Andaman and Nicobar Islands, India. Human Biology, 73, 739-744. https://doi.org/10.1353/hub.2001.0070

[60] Nkhoma, E.T., Poole, C., Vannappagari, V., Hall, S. and Beutler, E. (2009) The Global Prevalence of Glucose-6-Phosphate Dehydrogenase Deficiency: A Systematic Review and Meta-Analysis. Blood Cells, Molecules and Diseases, 42, 267-278. https://doi.org/10.1016/j.bcmd.2008.12.005 